\title{
Regulation of Bile Salt Transport in Rat Liver
}

\author{
EVIDENCE THAT INCREASED MAXIMUM BILE SALT \\ SECRETORY CAPACITY IS DUE \\ TO INCREASED CHOLIC ACID RECEPTORS
}

\author{
Francis R. Simon, Eileen M. Sutherland, and Manuel Gonzalez, Department \\ of Medicine, Division of Gastroenterology, University of Colorado Medical \\ School; Veterans Administration Hospital, Denver, Colorado 80262
}

\begin{abstract}
A B S T R A C T Expansion of the bile salt pool size in rats increases maximum excretory capacity for taurocholate. We examined whether increased bile salt transport is due to recruitment of centrolobular transport units or rather to adaptive changes in the hepatocyte. Daily sodium cholate (100 mg/100 g body wt) was administered orally to rats. This treatment was well tolerated for at least $4 \mathrm{~d}$ and produced an 8.2 -fold expansion of the bile salt pool. This expanded pool consisted predominently (99\%) of cholic and deoxycholic acids. Significantly increased bile salt transport was not observed until $16 \mathrm{~h}$ after bile acid loading, and maximum elevations of transport capacity to 2.3-fold of control required $\sim 2 \mathrm{~d}$. In contrast, maximum sulfobromophthalein excretion rates increased 2.2 -fold as early as $4 \mathrm{~h}$ and actually fell to 1.5 -fold increase at 4 d. We studied the possibility that this adaptive increase in bile salt secretory transport was due to changes in canalicular surface membrane area, lipid composition, or increased number of putative carriers. Canalicular membrane protein recovery and the specific activities of leucine aminopeptidase, $\mathrm{Mg}^{++}$-ATPase and $5^{\prime}$-nucleotidase activities were unaltered by bile salt pool expansion. The content of free and esterified cholesterol and total phospholipids was unchanged in liver surface membrane fractions compared with control values. In contrast, sodium cholate administration se-
\end{abstract}

This work was presented, in part, at the American Association for the Study of Liver Diseases, Salt Lake City, UT, 21 May 1980, and appeared in abstract form in 1980. Gastroenterology. 78: 1322a.

Dr. Gonzalez' present address is University of Chile School of Medicine, Department of Gastroenterology, Hospital Salvador, Santiago 9, Chile.

Received for publication 29 June 1981 and in revised form 15 March 1982. lectively increased specific $\left[{ }^{14} \mathrm{C}\right]$ cholic acid binding sites twofold in liver surface membrane fractions. Increased numbers of $\left[{ }^{14} \mathrm{C}\right]$ cholic acid receptors $(a)$ was associated with the time-dependent increase in bile salt transport, and $(b)$ was selective for the taurine conjugate of cholate and $(c)$ was reduced by chenodeoxycholate. Changes in bile acid binding sites $16 \mathrm{~h}$ following taurocholate and chenodeoxycholate and the lack of change with glycocholate was associated with comparable changes in bile salt transport. In conclusion, selective bile salts increase bile salt transport in the liver through an adaptive increase in the density of putative bile acid carriers in liver surface membrane.

\section{INTRODUCTION}

Bile salts circulate efficiently in an enterohepatic pool whose size is determined, in part, by active transport mechanisms located in ileal epithelial and liver cells. In the liver, bile salts are rapidly cleared from the portal blood by a well characterized sodium-dependent carrier-mediated process (1-3). In contrast, cellular translocation and biliary seretion are poorly understood. Presumably, bile salts are excreted across the canalicular surface membrane by a carrier-mediated process independent of sodium gradients, since it has been shown that secretion reaches a maximum value in the face of a rising concentration in the blood (4), there is competition between different bile salts (5), and ouabain fails to inhibit secretion in isolated hepatocytes (6). Maximum excretory capacity (Tm) ${ }^{1}$ for taurocholate, similar to bilirubin (7) and bromosulfophthalein (BSP) (8), has been shown to be the

\footnotetext{
${ }^{1}$ Abbreviations used in this paper: BSP, bromsulfophthalein; Tm, maximum excretory capacity.
} 
rate-limiting step in its overall transport $(9,10)$. In bile secretory failure a decrease in the maximum transport capacity may be the only step which is altered $(11,12)$.

Several lines of evidence have suggested that bile salt carriers are important in the regulation of bile secretion: $(a)$ bile salt receptors, whose affinity is independent of the sodium concentration, have been identified and characterized in liver surface membrane fractions (13); and (b) maximum taurocholate excretion rates decrease as the number of bile salt receptors decreases (14). In addition to the number of bile salt carriers, membrane lipid composition and fluidity are also major determinants of bile salt excretion $(15,16)$. These associations have suggested the hypothesis that alterations in either specific bile salt receptors or membrane lipid composition are important determinants of maximum bile salt transport. However, these correlations have been observed only with experimental models of decreased bile salt excretory capacity.

It has been reported that the liver is capable of responding to an increased load of bile salts by increasing bile salt maximum secretory capacity (17). Since bile salt administration produces many intracellular changes in metabolism, the cellular mechanism responsible for increased transport capacity is unclear. The aim of the present study is to determine the cellular mechanism of this effect, namely, whether increased bile salt transport is due to recruitment or to adaptive changes in the liver cell. Specifically, we examined in rats with expanded bile salt pools whether increases in bile salt transport are $(a)$ associated with alterations in maximum secretory rates for other organic anions (BSP), (b) associated with changes in the surface membrane lipid composition or an increase in the number of bile salt receptors, and $(c)$ whether the changes are specific to bile salt structure and/or detergent properties. The results demonstrate that selective bile salts increase hepatic transport through an increase in the number of putative bile salt carriers.

\section{METHODS}

Materials. [24-carboxyl $\left.-{ }^{14} \mathrm{C}\right]$ Cholic acid $(45 \mathrm{mCi} / \mathrm{mmol}$, 99\% radiochemically pure) was obtained from New England Nuclear (Boston, MA). The following unlabeled bile acids were obtained from Maybridge Research Chemicals (Cornwall, England): cholic, taurocholic, glycocholic, chenodeoxycholic, taurochenodeoxycholic, taurodeoxycholic, and taurodehydrocholic acids. Ursodeoxycholic acid was kindly supplied as $99+\%$ pure, by Giuliani (Milan, Italy). All bile acids were of the highest purity available and found to be $99 \%$ pure by thin-layer chromotography. Triton WR-1339 (oxyethylated tertiary oxtylphenol polymethylene polymer) was obtained from Ruger Chemical Company, Inc. (Irvington, NY). Albumin (bovine), ouabain, AMP, disodium ATP, $\beta$ steroid dehydrogenase, 2,6-dichlorophenolindophenol, $L$ - leucyl- $\beta$-naphylamide $\mathrm{HCl}$, lactic dehydrogenase, glucose-6phosphate, and pyruvate kinase were the highest purity available from Sigma Chemical Co. (St. Louis, MO). BSP was obtained from Hynson, Westcott, \& Dunning (Baltimore, MD).

Treatment groups. Male Sprague-Dawley rats (Charles River Breeding Laboratories Inc., Wilmington, MA) were used. The animals weighed $\sim 200 \mathrm{~g}$ at the start of the experiments. Throughout the studies rats were subjected to darkness between 1800 and 0600 , and light between 0600 and 1800. Animals received each evening sodium cholate $100 \mathrm{mg} / 100 \mathrm{~g}$ body wt by oral nasogastric tube under light ether anesthesia. The cholic acid solution was made up in normal saline by carefully adjusting the initial solution to pH 7.4 with $5 \mathrm{~N} \mathrm{NaOH}$. The final concentration of cholic acid was $200 \mathrm{mg} / \mathrm{ml}$. Animals had free access to food (Purina Rat Chow, Ralston Purina Co., St. Louis, MO) and tap water, except the evening before killing when food was withheld.

In chronic studies, animals were given cholic acid daily for $4 \mathrm{~d}$ and killed the following morning. Randomly selected rats were treated and handled in a similar manner except that $0.9 \%$ saline instead of cholic acid was given by nasograstric tube. Daily intake of rat chow and body weight were measured.

In acute experiments ( $16 \mathrm{~h})$, all bile acids except taurodehydrocholic acid were prepared and administered in a similar manner the evening before study. Taurodehydrocholate and the detergent Triton WR-1339 were administered intraperitoneally to assure complete delivery to the liver.

Bile acid determination. Total bile acid pool size was determined by biliary drainage according to the method of Mok et al. (18). In treated animals, as well as controls, basal hepatic bile acid synthesis was determined from the low point in bile acid secretion and was subtracted from the total amount of bile salt produced over $20 \mathrm{~h}$. Generally, in control animals basal synthesis was reached in the 10-12-h sample, while in treated rats basal synthesis rates were not reached until the 14-16-h collection period. Bile salts were measured using the $\beta$-steroid dehydrogenase assay described by Talalay (19). Biliary bile salt species were identified and quantitated by gas-liquid chromatography on samples collected during the first $4 \mathrm{~h}$ of biliary drainage. Bile was hydrolyzed in methanol and $4 \mathrm{~N} \mathrm{NaOH}$ using 5 - $\beta$-cholanic acid as an internal standard (20). The bile acids were then extracted, methylated with diazomethane, and trimethylsilyl derivatives were prepared (21), gas-liquid chromatography was performed on 6 - $\mathrm{ft}$ glass columns at $200^{\circ} \mathrm{C}$ using $1 \%$ HiEff$8 \mathrm{BP}$ on $100 / 120$ mesh gas chrom $Q$ packing, with helium as the carrier gas at $30 \mathrm{ml} / \mathrm{min}$ (20). A Perkin-Elmer model 3920 gas chromatograph (Perkin-Elmer Corp., Instrument Div., Norwalk, CT) was used for all analyses. Bile acid reference standards were those previously used in Dr. Fred Kern's laboratory (22).

Hepatic bile acid and BSP maximal transport capacities. Maximal transport capacity for bile salts and BSP was measured as previously described (14). To determine bile salt $\mathrm{Tm}$, taurocholate was infused through either the subclavian or the femoral vein using a PE 50 catheter. The infusion, using a Harvard pump (Harvard Apparatus Co., Inc., S. Natick, MA) was started immediately after the basal period at a progressive rate from 0.5 to $3.5 \mu \mathrm{mol} / \mathrm{min}$ per $100 \mathrm{~g}$ body wt or until cholestasis was noted. Bile was collected in preweighed tubes in 10-min periods for $30 \mathrm{~min}$ at each bile salt concentration, through either a PE-10 or PE-50 catheter located just distal to the bifurcation of the common bile duct. Body temperature was maintained at $37 \pm 0.5^{\circ} \mathrm{C}$ with use of 
a heating lamp. BSP Tm was determined by an infusion of $\mathrm{BSP}$ at a $0.30 \mu \mathrm{mol} / \mathrm{min}$ per $100 \mathrm{~g}$ body wt through a femoral vein in control animals, and at $0.50 \mu \mathrm{mol} / \mathrm{min}$ per $100 \mathrm{~g}$ body wt in cholate-treated rats. Conjugated BSP was demonstrated in the serum of both animal groups documenting that BSP Tm was achieved.

Analysis of liver surface membrane enzymes and lipids. Liver surface membrane fractions were isolated by the method of Neville (23) through step 12 as described by Pohl et al. (24) and previously characterized in our laboratory (13-16). Surface membrane fraction purification was determined by marker enzymes (13-16). 5'-Nucleotidase (EC 3.1.3.5) was measured by the method of Song and Bodansky (25), glucose-6-phosphatase (EC 3.1.3.9) according to deDuve et al. (26), succinic dehydrogenase (EC 1.3.99.1) as described by Seubert (27), using 2,6-dichlorophenolindophenol as the donor. The decrease in absorbance was measured at $600 \mathrm{~nm}$, and enzyme activity was calculated using an extinction coefficient of $1610 \mathrm{~L} \mathrm{~cm}^{-1} \mathrm{~mol}^{-1}$. Proteins were measured by the method of Lowry et al. (29) using bovine serum albumin as standard, and phosphorous was determined according to Fiske and SubbaRow (30). Leucine aminopeptidase (EC 3.4.11.1) was determined according to Goldberg and Ratenburg (28) with L-leucyl- $\beta$-napthylamide $\mathrm{HCl}$ as substrate. Magnesium-dependent ATPase was that activity measured in the presence of $2.4 \mathrm{mM}$ ouabain using a coupled enzyme system as described by Schoner et al. (29).

Following chloroform/methanol extraction according to Folch et al. (33), phospholipids were determined by the method of Bartlett (32), assuming 780 average molecular weight for phospholipids. Free and esterified cholesterol was determined after extraction (33) and quantitated by gas-liquid chromatography (34).

Bile acid binding assay. The binding of $\left[{ }^{14} \mathrm{C}\right]$ cholic acid (45 $\mathrm{mCi} / \mathrm{mmol}$, New England Nuclear) was determined as previously described (13). In brief, the binding reaction was started by adding surface membrane fractions to the incubation medium that contained $132 \mathrm{mM}$ monosodium phosphate/disodium phosphate buffer, $\mathrm{pH} 6.0$ and $\left[{ }^{14} \mathrm{C}\right] \mathrm{cholic}$ acid. The samples were incubated in a shaking water bath at $4^{\circ} \mathrm{C}$ for $20 \mathrm{~min}$ and the reaction terminated by rapid vacuum filtration (Hoeffer Scientific Instruments, San Francisco, CA) to separate membrane bound from free ${ }^{14} \mathrm{C}$-labeled cholic acid. Membrane bound $\left[{ }^{14} \mathrm{C}\right] \mathrm{cholic}$ acid was collected on glass fiber disks (Whatman grade GF/C, Whatman, Inc., Chemical Separation Div., Clifton, NJ) and measured in triplicate.

Free bile acid concentration was estimated by subtracting the total bile acid bound per sample from the total amount of bile acid present in the assay. "Nonspecific" interactions of labeled bile acids with membrane fractions was determined after preincubation of the liver surface membranes at $37^{\circ} \mathrm{C}$ for $3-5 \mathrm{~h}$ to denature the specific bile acid binding sites (13). Specific bile acid binding is assumed to be that fraction remaining after subtracting from the total the value obtained with heat-denatured membranes.

Liver function tests. Serum samples from fasting control and 4-d cholic acid-treated rats were obtained from the portal vein. Serum bilirubin, albumin, and alanine aminotransferase (EC 2.6.1.2; serum glutamic pyruvic transaminase) were determined in the Pediatric Microchemistry Laboratory of the University of Colorado School of Medicine using standard methods (14).

Statistical analysis. Linear regression analyses were performed by the least squares method. Specific cholic acid binding constants were estimated by a nonlinear least squares regression program and variances compared by an $\mathrm{F}$ test. Means of groups were compared by Student's $t$ test; analysis of variance was used for statistical comparison. $P$ values $<0.05$ were considered significant. Values are expressed as mean \pm SEM.

\section{RESULTS}

General effects of cholic acid loading. Oral administration of sodium cholate for $4 \mathrm{~d}$ to male SpragueDawley rats does not significantly change growth, liver size, serum tests of liver function, or hepatocellular integrity (Table I). Stools in cholate-fed rats were softer than in controls, although no significant diarrhea was noted. No significant morphological changes were observed in the liver by either light or electron microscopy, and in the small intestine by light microscopy.

Daily cholate administration for $4 \mathrm{~d}$ expands the total bile salt pool size 8.2-fold (Table II). As previously found (20), cholic acid $(60.9 \pm 3.2 \%)$ is the major bile salt in rat bile with smaller amounts of deoxycholic $(6.0 \pm 1.1 \%)$ and chenodeoxycholic $(7.0 \pm 0.7 \%)$ acids. Other bile acids found in control samples include $\beta$ muricholic, hyodeoxycholic, lithocholic, and ursodeoxycholic acids. These bile acids accounted for

TABLE I

Effect of Cholate Feeding on Growth and Liver Function Tests

\begin{tabular}{|c|c|c|c|c|c|c|}
\hline & \multirow[b]{2}{*}{$\begin{array}{c}\text { Initial } \\
\text { body weight }\end{array}$} & \multirow[b]{2}{*}{ Weight gain } & \multirow[b]{2}{*}{$\frac{\text { Liver }}{\text { Body }} w t \times 100$} & \multicolumn{3}{|c|}{ Serum } \\
\hline & & & & Bilirubin & Albumin & GPTt \\
\hline & $g$ & $g / d$ & & $m g / d l$ & $g / d l$ & $I U / d l$ \\
\hline Control (6) & $206 \pm 7$ & $7.3 \pm 0.6$ & $3.9 \pm 0.2$ & $0.2 \pm 0.02$ & $4.3 \pm 0.2$ & $42 \pm 5$ \\
\hline Cholic acid $^{\bullet}(5)$ & $197 \pm 8$ & $7.5 \pm 0.7$ & $3.7 \pm 0.2$ & $0.2 \pm 0.03$ & $4.3 \pm 0.2$ & $47 \pm 8$ \\
\hline$P$ value & NS & NS & NS & NS & NS & NS \\
\hline
\end{tabular}

- Cholic acid (100 mg/100 g body wt) was administered orally each day for $4 \mathrm{~d}$, while controls received saline. Values are expressed as mean \pm SEM. Parentheses represent the number of separate experiments.

† Alanine aminotransferase. Wt, weight. 
TABLE II

Bile Salt Pool Size and Composition

\begin{tabular}{|c|c|c|c|c|c|}
\hline & \multirow[b]{2}{*}{ Bile salt pool size } & \multicolumn{4}{|c|}{ Bile acid composition } \\
\hline & & Cholate & Deoxycholate & Chenodeoxycholate & Other \\
\hline & $m g / 100 \mathrm{~g}$ body $w t$ & \multicolumn{4}{|c|}{$\mu \mathrm{mol} / 100 \mathrm{~g}$ body $w t$} \\
\hline Control (4) & $12.4 \pm 3.2$ & $20.5 \pm 2.0$ & $2.1 \pm 0.5$ & $2.4 \pm 0.3$ & $8.5 \pm 4.3$ \\
\hline Cholic acid (4) & $102 \pm 21$ & $221.8 \pm 28.3$ & $71.6 \pm 30.5$ & $0.8 \pm 0.8$ & $4.1 \pm 4.1$ \\
\hline Fold change & 8.2 & 10.8 & 33.3 & 0.3 & 0.5 \\
\hline$P$ value & $<0.001$ & $<0.001$ & $<0.001$ & NS & NS \\
\hline
\end{tabular}

Cholic acid was administered orally $(100 \mathrm{mg} / 100 \mathrm{~g}$ body wt for $4 \mathrm{~d})$. Bile acid pool size was measured by biliary drainage over $24 \mathrm{~h}$ on day 5 . Bile acid analysis was performed on an aliquot of bile obtained during the initial $4 \mathrm{~h}$ of drainage and measured by gas-liquid chromatography (Methods). Values are expressed as mean $\pm \mathrm{SEM}$.

$24.0 \pm 3.4 \%$ and are combined in Table II under "Other." After cholate administration the bile acid pool was almost entirely converted to cholic and deoxycholic acids, i.e., $99 \%$ of the bile acid pool. Chenodeoxycholic and the "other" bile acids were reduced to negligible levels. Indeed, only one of four rats fed cholate had measurable amounts of these bile acids, accounting for the large variation and the lack of a statistically significant decrease in their content.

Hepatic excretory function. In animals with expanded bile acid pools, basal bile flow and bile salt secretion are significantly increased 2- and 3.8-fold, respectively (Table III). In treated rats, basal bile salt secretion rates approached the maximum bile salt excretion capacity of controls. However, in cholatetreated animals maximum taurocholate secretion was increased 2.3-fold, thereby maintaining a significant secretory reserve capacity. Cholate feeding also in- creased the maximum transport capacity for BSP to $156 \%$ of control values.

Rapid recruitment of reserve transport capacity has previously been shown for BSP excretion after bile salt infusions $(35,36)$. To examine whether similar mechanisms are involved in increasing bile salt $\mathrm{Tm}$, the time course for changes in BSP and bile acid transport were compared (Fig. 1). $4 \mathrm{~h}$ after cholic acid administration bile acid $\mathrm{Tm}$ is unchanged while BSP Tm is 2.2 -fold greater than control values. At $16 \mathrm{~h}$ bile salt $\mathrm{Tm}(135 \%$ of control) is now significantly $(P<0.05)$ increased, but does not reach its maximum transport rate until $\sim 2 \mathrm{~d}$ and then remains unchanged for at least $4 \mathrm{~d}$ during continued cholate administration. In contrast, BSP Tm falls to $156 \%$ of control of $16 \mathrm{~h}$ and is unchanged for at least $4 \mathrm{~d}$.

Hepatic lipid content. Bile salt infusions are known to change hepatic lipid synthesis and to increase biliary

TABLE III

Effect of Cholate Feeding on Hepatic Excretory Function

\begin{tabular}{|c|c|c|c|c|}
\hline & \multicolumn{2}{|c|}{ Initial secretion } & \multicolumn{2}{|c|}{$\operatorname{Tm}$} \\
\hline & Bile flow & Bile salt & Taurocholate & BSP \\
\hline & \multicolumn{2}{|c|}{$\mu \mathrm{l} / \mathrm{min} / 100 \mathrm{~g}$ body $w t$} & \multicolumn{2}{|c|}{$\mu \mathrm{mol} / \min / 100 \mathrm{~g}$ body $w t$} \\
\hline Control (9) & $7.6 \pm 1.8$ & $0.26 \pm 0.11$ & $1.0 \pm 0.1$ & $0.213 \pm 0.003$ \\
\hline Cholic acid (5) & $15.0 \pm 0.8$ & $0.94 \pm 0.10$ & $2.3 \pm 0.2$ & $0.332 \pm 0.022$ \\
\hline Percent change & $199 \%$ & $381 \%$ & $230 \%$ & $156 \%$ \\
\hline$P$ value & $<0.005$ & $<0.005$ & $<0.005$ & $<0.01$ \\
\hline
\end{tabular}

Initial biliary secretory function was measured during the first $30 \mathrm{~min}$ after cannulation of the bile duct. Taurocholate and BSP Tm were determined as described in Methods. Numbers in parentheses indicate separate determinations. Values are expressed as mean \pm SEM. 


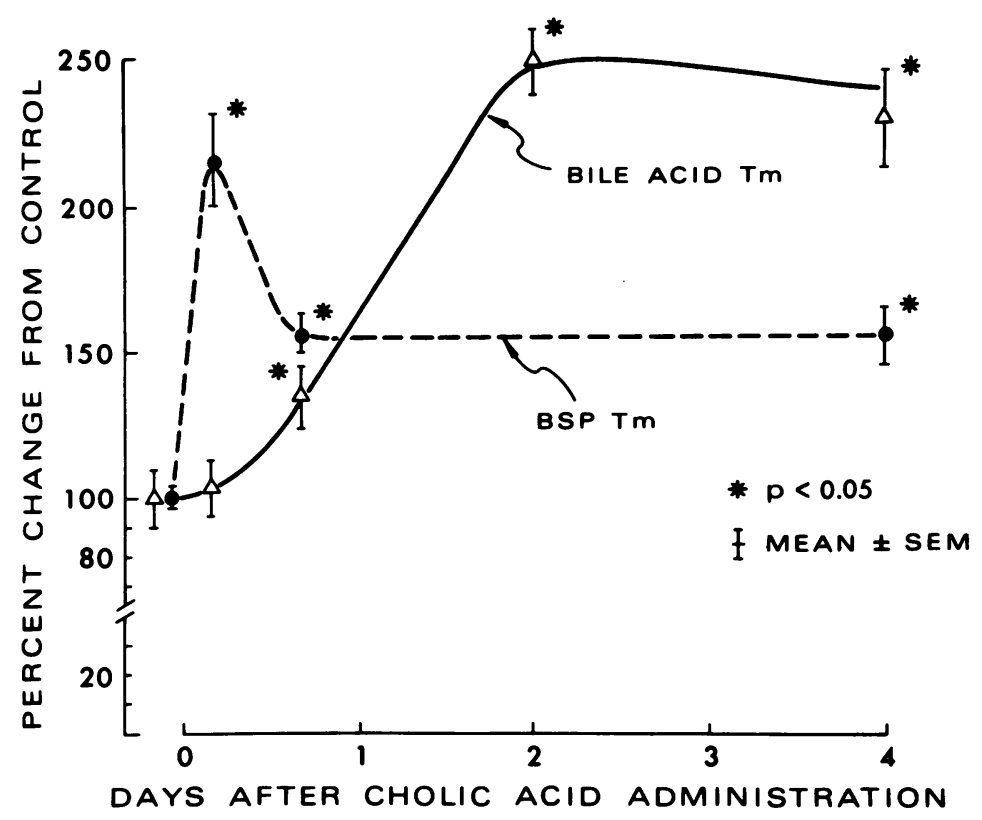

FIGURE 1 Effect of cholic acid feeding on maximum transport capacity for taurocholate and BSP. Sodium cholate (100 mg/100 g body wt, orally) was administered daily, and transport capacity determined (Methods) using PE 10 bile duct cannulas. Each point is the mean \pm SEM for four to six determinations. The values for control ${ }^{-1}$ taurocholate Tm $1.0 \pm 0.1 \mu \mathrm{mol} \cdot \mathrm{min}$.

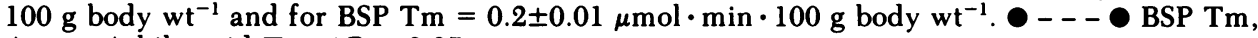

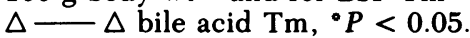

lipid secretion (37-40). To determine whether changes in bile salt transport may be due to alterations in membrane lipid composition, total phospholipids and cholesterol content was determined in liver surface membrane fractions after feeding sodium cholate for $4 \mathrm{~d}$ and values compared with control animals. The content of phospholipid $(449 \pm 21$ vs. $416 \pm 19 \mu \mathrm{g} / \mathrm{mg}$ protein), free cholesterol $(90.8 \pm 6.3$ vs. $93.4 \pm 4.9 \mu \mathrm{g} / \mathrm{mg}$ protein), and esterified cholesterol ( $4.4 \pm 1.3 \mathrm{vs.} 3.4 \pm 1.6$ $\mu \mathrm{g} / \mathrm{mg}$ protein) in liver surface membrane fractions was not significantly changed by cholate feeding. Thus, the cholesterol to phospholipid molar ratio, an important determinant of membrane lipid fluidity (41), was not significantly different from controls $(0.58 \pm 0.05$ vs. $0.53 \pm 0.06)$.

Liver surface membrane recovery, enzyme activities, and bile acid binding. Recovery of liver surface membrane fractions after $4 \mathrm{~d}$ of cholate feeding was unaltered as judged by protein recovery and marker enzymes (Table IV). Neither specific activities nor relative enrichment of enzymes for the surface membrane including $5^{\prime}$-nucleotidase, $\mathbf{M g}^{++}$-ATPase, and leucine aminopeptidase were significantly changed. Although glucose-6-phosphatase was unaltered, succinic dehydrogenase, a marker of the mitrochondria, was moderately increased $(P<0.05)$ in surface membrane fractions from sodium cholate-treated rats. In contrast, the maximum number of specific $\left[{ }^{14} \mathrm{C}\right]$ cholic acid binding sites was increased $(23.8 \pm 1.4$ to $41.3 \pm 5.1$ $\mathrm{nmol} / \mathrm{mg}$ protein, $P<0.01$ ) by cholate treatment for $4 \mathrm{~d}$ (Table IV). The number of nonspecific bile acid binding sites was unchanged compared with control values, indicating that the increase in bile salt receptors was selective.

To examine whether cholic acid treatment increased a heterogeneous number of receptor sites, binding kinetics were analyzed by Scatchard analysis (Fig. 2) (42). Bile acid binding parameters indicate that the dissociation constant $\left(K_{d}\right)$ for $\left[{ }^{14} \mathrm{C}\right]$ cholic acid was similar in treated $(1.20 \pm 0.19 \mathrm{mM})$ and control $(1.16 \pm 0.12$ $\mathrm{mM}$ ) liver surface membrane fractions, while the maximum binding capacity $(\mathrm{N})$ was significantly $(P<0.01)$ increased twofold $(33.8 \pm 8.2$ vs. $64.2 \pm 10.0 \mathrm{nmol} / \mathrm{mg}$ protein). These results suggest that cholate feeding increases a single homogeneous set of receptors without evidence for cooperative interactions.

The time course and magnitude of changes in bile acid binding are shown in Fig. 3. These changes are compared to those previously described for taurocholate $\mathrm{Tm}$. Both bile acid binding and transport demonstrate a latent period of at least $4 \mathrm{~h}$, since no significant changes are noted up to that point. Both parameters are significantly increased at $16 \mathrm{~h}$ after a single oral feeding of sodium cholate. Specific binding 
TABLE IV

Effect of Cholate Administration on Liver Surface Membrane Protein Recovery, Enzyme Activities, and $\left[{ }^{14} \mathrm{C}\right]$ Cholic Acid Binding

\begin{tabular}{|c|c|c|c|c|c|c|c|c|}
\hline & \multirow[b]{2}{*}{$\underset{\text { recovery }}{\text { LSM }}$} & \multirow[b]{2}{*}{$5^{\prime}$-Nucleotidase } & \multirow[b]{2}{*}{$\begin{array}{l}\mathrm{Mg}^{++} \text {. } \\
\text { ATPase }\end{array}$} & \multirow[b]{2}{*}{$\begin{array}{l}\text { Leucine ami- } \\
\text { nopeptidase }\end{array}$} & \multirow[b]{2}{*}{$\begin{array}{l}\text { Glucose-6- } \\
\text { phosphatase }\end{array}$} & \multirow[b]{2}{*}{$\begin{array}{l}\text { Succinic dehy- } \\
\text { drogenase }\end{array}$} & \multicolumn{2}{|c|}{$\left[{ }^{14} \mathrm{C}\right]$ Cholic acid binding } \\
\hline & & & & & & & Specific & Nonspecific \\
\hline & $\begin{array}{c}\text { mg protein/ } \\
\text { g liver }\end{array}$ & \multicolumn{2}{|c|}{$\mu$ mol $P i / h / m g$ protein } & 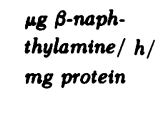 & $\begin{array}{c}\mu m \mathrm{P} i / h / \\
m g \text { protein }\end{array}$ & $\begin{array}{l}\text { umol dichloro- } \\
\text { phenol-indeo- } \\
\text { phenol/min/ } \\
\text { mg protein }\end{array}$ & \multicolumn{2}{|c|}{ nmol/mg protein } \\
\hline Control & $1.6 \pm 0.3$ & $\begin{array}{c}41.4 \pm 2.8 \\
(13 \times)\end{array}$ & $\begin{array}{c}79.9 \pm 7.8 \\
(9 \times)\end{array}$ & $\begin{array}{c}1.07 \pm 0.07 \\
(5 \times)\end{array}$ & $\begin{array}{c}2.8 \pm 0.2 \\
(0.5 \times)\end{array}$ & $\begin{array}{c}64.5 \pm 4.6 \\
(4 \times)\end{array}$ & $23.8 \pm 1.4$ & $4.3 \pm 0.9$ \\
\hline Cholic acid & $1.4 \pm 0.1$ & $\begin{array}{l}41.7 \pm 1.6 \\
(13)\end{array}$ & $\begin{array}{c}86.9 \pm 4.8 \\
(11)\end{array}$ & $\begin{array}{c}0.95 \pm 0.2 \\
(5)\end{array}$ & $\begin{array}{c}2.0 \pm 0.3 \\
(0.4)\end{array}$ & $\begin{array}{c}85.2 \pm 7.8 \\
(5)\end{array}$ & $41.3 \pm 5.1$ & $3.6 \pm 0.2$ \\
\hline Percent change & $-14 \%$ & $+1 \%$ & $+9 \%$ & $-11 \%$ & $-29 \%$ & $+32 \%$ & $+74 \%$ & $-16 \%$ \\
\hline$P$ value & NS & NS & NS & NS & NS & $<0.05$ & $<0.01$ & NS \\
\hline
\end{tabular}

Liver surface membrane (LSM) fractions were prepared through step 12 of Neville (23) and enzymatic activities determined as described in Methods. $\left[{ }^{14} \mathrm{C}\right.$ Cholic acid binding was determined (Methods) using an initial concentration of cholic acid of $1.8 \mathrm{mM}$. Values are mean \pm SEM. The numbers of separate experiments are shown in parentheses. Cholic acid $(100 \mathrm{mg} / 100 \mathrm{~g}$ body wt) was administered orally for $4 \mathrm{~d}$. Values in parentheses ( ) indicate the relative specific activities (surface membrane/homogenate).

and bile salt transport both rise to a maximum between 24-48 $\mathrm{h}$, where despite further cholate administration, the number of $\left[{ }^{14} \mathrm{C}\right]$ cholic acid receptors and $\mathrm{Tm}$ remain unchanged, indicating that a new steady state has been achieved.
Structural specificity for increase in hepatic bile acid binding and transport. To examine whether the structure or detergent properties of bile salts are the important determinants in increasing the number of $\left[{ }^{14} \mathrm{C}\right]$ cholic acid binding sites, receptors were deter-

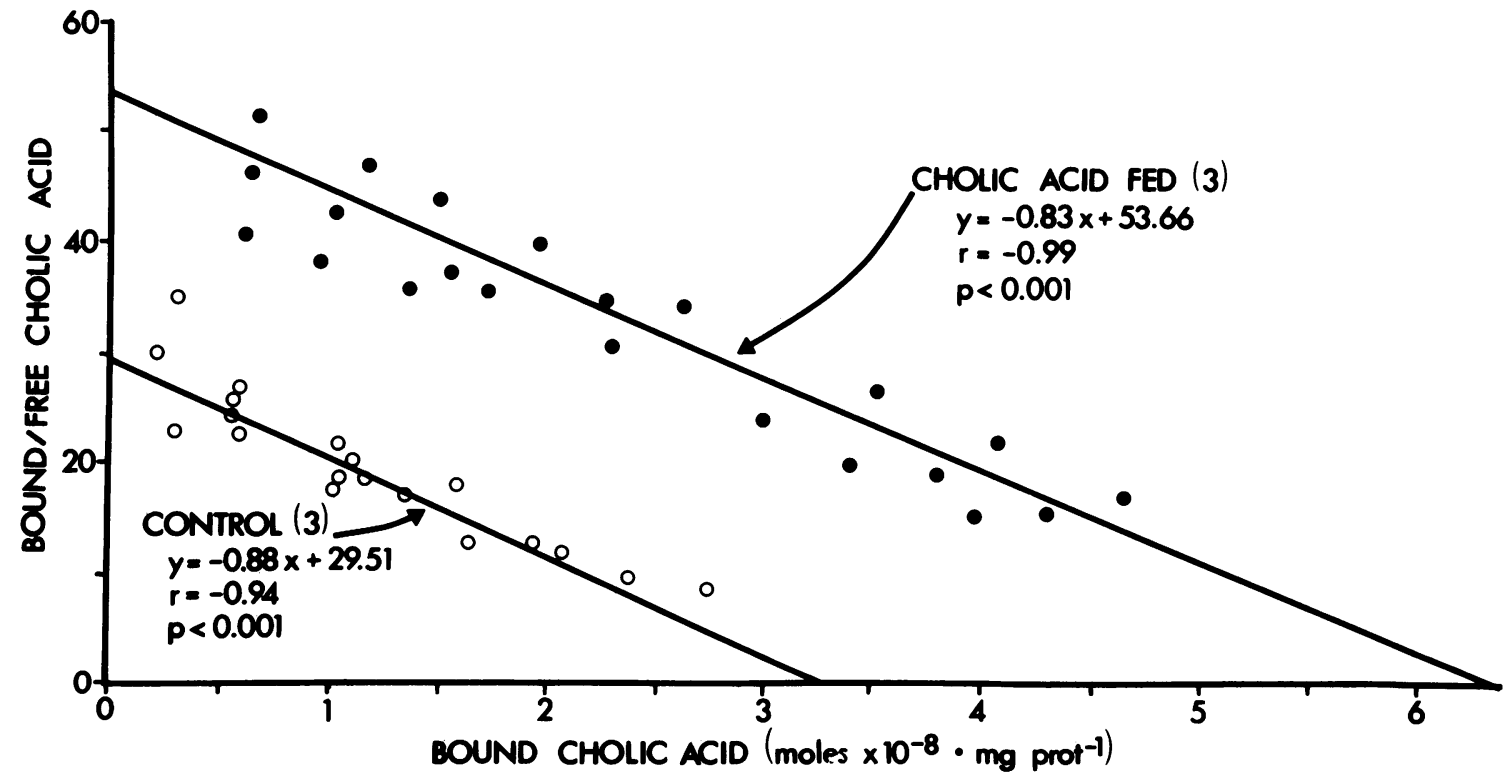

Figure 2 Scatchard analysis of specific $\left[{ }^{14} \mathrm{C}\right]$ cholic acid binding to liver surface membrane fractions from control and cholic acid-fed rats. Plotted data correspond to specific cholic acid binding values determined from binding kinetics between the concentrations of 0.1 and 2.2 $\mathrm{mM}$. The best-fit linear function was determined by least-squares regression. The value of $\mathrm{N}$ (maximum binding capacity), estimated by extrapolating the line to the abscissa, is 33.8 and $64.2 \mathrm{nmol} / \mathrm{mg}$ membrane protein and of $K_{d}$, estimated as $1 / \mathrm{slope}$ is 1.1 and $1.2 \mathrm{mM}$ from control and cholic acid-treated rats, respectively. Cholic acid (100 mg/100 $\mathrm{g}$ body wt, orally) was administered daily for $4 \mathrm{~d}$ and liver surface membrane fractions and $\left[{ }^{14} \mathrm{C}\right]$ cholic acid binding determined as described in Methods. Numbers in parentheses indicate number of separate experiments in each group. 


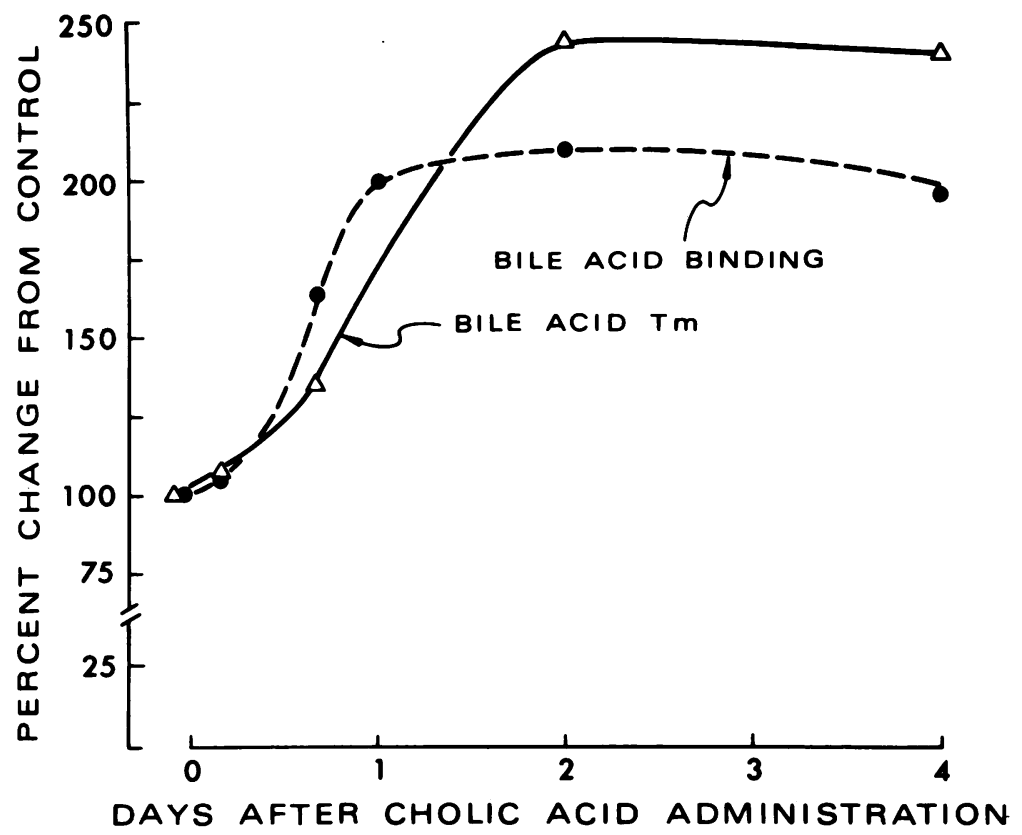

Figure 3 . Relationship of bile acid $\mathrm{Tm}$ to the number of specific $\left[{ }^{14} \mathrm{C}\right] \mathrm{cholic}$ acid binding sites following cholic acid feeding. Taurocholate $\mathrm{Tm}$ was determined as described in Methods and previously shown in Fig. $1 .\left[{ }^{14} \mathrm{C}\right]$ Cholic acid binding was determined in four to six separate determinations in liver surface membrane fractions by ultrafiltration using a cholic acid concentration of $1.8 \mathrm{mM}$. Control values for taurocholate $\mathrm{Tm}$ is $1.0 \pm 0.1 \mu \mathrm{mol} / \mathrm{min}$ per $100 \mathrm{~g}$ body wt (9 determinations) and for specific cholic acid binding is $26.4 \pm 1.1 \mathrm{nmol} / \mathrm{mg}$ protein (10 determinations). Each point is the mean of 4-10 determinations. All points from $16 \mathrm{~h}$ on were statistically significant at $\boldsymbol{P}<0.05$.

mined in liver surface membrane fractions $16 \mathrm{~h}$ after the oral administration of different bile salts and a nonbile salt detergent (Table V). Both cholate (158\%) and taurocholate (199\%) increased the maximum number of bile acid receptors compared with control, while glycocholate (113\%) failed to significantly increase the number of bile acid receptors. No other tested bile salts or the nonbile salt detergent (Triton WR-1339) significantly increased the maximum number of $\left[{ }^{14} \mathrm{C}\right]$ cholic acid binding sites. In contrast, chenodeoxycholate significantly reduced to $71 \%$ of control the density of bile acid binding sites. This effect was prevented by taurine conjugation of chenodeoxycholate. Furthermore, administration of bile salts did not significantly alter recovery of liver surface membrane fractions since protein recovery and the relative enrichment of marker enzymes was unchanged (Table V).

The apparent specificity for increasing cholic acid binding sites was examined further by determining the effect of administration of different bile salts on bile flow and taurocholate Tm (Table VI). Tauro and glyco conjugates of cholate both significantly increased initial bile flow and bile salt excretion to a similar extent. Oral administration of chenodeoxycholate altered nei- ther bile flow nor bile salt excretion. Although both conjugates of cholate produce similar changes in bile flow, only taurocholate significantly increases taurocholate transport maximum. Similar to its effects on cholic acid binding sites chenodeoxycholate administration proportionately reduces taurocholate $\mathrm{Tm}$. Analysis of the correlation between changes in the number of cholate binding sites and taurocholate $\mathrm{Tm}$ after oral administration of different bile salts demonstrates a strong association $(r=0.993, P<0.01)$.

\section{DISCUSSION}

Hepatic transport of bile salts is a complex process involving at least the following steps that may be unevenly distributed across a lobular gradient (43): sodium-dependent uptake into hepatocytes $(6,10)$, translocation across the cell (44), and biliary excretion presumably by a separate carrier-mediated process (45). Under normal conditions, biliary secretory capacity is believed to be the rate-limiting step in hepatic transport (46). In previous studies we have suggested that the number of putative bile acid carriers and/or the lipid composition and structure of the liver surface membrane are important determinants of this maximum bile salt secretory transport rate (14-16). 
TABLE V

Effect of Different Bile Salts and Detergents on Specific $\left[{ }^{14} \mathrm{C}\right]$ Cholate Binding and Liver Surface Membrane Recovery

\begin{tabular}{|c|c|c|c|c|c|}
\hline & \multirow[b]{2}{*}{$\begin{array}{l}\text { Specific }\left[{ }^{14} \mathrm{C}\right] \text { cholate } \\
\text { binding }\end{array}$} & \multirow[b]{2}{*}{$\begin{array}{l}\text { Surface membrane } \\
\text { protein recovery }\end{array}$} & \multicolumn{3}{|c|}{ Relative enrichment (Liver plasma membrane homogenate) } \\
\hline & & & 5'-Nucleotidase & $\begin{array}{c}\text { Succinic } \\
\text { dehydrogenase }\end{array}$ & $\begin{array}{l}\text { Glucose-6- } \\
\text { phosphatase }\end{array}$ \\
\hline & $\%$ of control & $m g \cdot g$ liver $^{-1}$ & & & \\
\hline Control & $\begin{array}{r}100 \pm 9 \\
(23)\end{array}$ & $\begin{array}{c}(6) \\
1.6 \pm 0.3\end{array}$ & $\begin{array}{c}(3) \\
13 \pm 3\end{array}$ & $\begin{array}{c}(3) \\
4 \pm 1\end{array}$ & $\begin{array}{c}(3) \\
0.5 \pm 0.1\end{array}$ \\
\hline Cholate & $\begin{array}{c}158 \pm 20^{\circ} \\
(16)\end{array}$ & $1.4 \pm 0.1$ & $13 \pm 3$ & $5 \pm 1$ & $0.4 \pm 0.3^{\circ}$ \\
\hline Taurocholate & $\begin{array}{c}199 \pm 23^{\circ} \\
(12)\end{array}$ & $1.4 \pm 0.3$ & $12 \pm 2$ & $3 \pm 1$ & $0.5 \pm 0.2$ \\
\hline Glycocholate & $\begin{array}{c}113 \pm 20 \\
(11)\end{array}$ & $1.8 \pm 0.1$ & $10 \pm 1$ & $3 \pm 1$ & $0.7 \pm 0.1$ \\
\hline Chenodeoxycholate & $\begin{array}{c}71 \pm 15^{\circ} \\
(7)\end{array}$ & $1.6 \pm 0.1$ & $10 \pm 1$ & $2 \pm 1$ & $0.5 \pm 0.2$ \\
\hline Taurochenodeoxycholate & $\begin{array}{c}97 \pm 14 \\
(9)\end{array}$ & $2.1 \pm 0.5$ & $15 \pm 3$ & $5 \pm 1$ & $0.5 \pm 0.1$ \\
\hline Ursodeoxycholate & $\begin{array}{c}81 \pm 14 \\
(12)\end{array}$ & $1.6 \pm 0.1$ & $11 \pm 1$ & $4 \pm 1$ & $0.4 \pm 0.1$ \\
\hline Taurodeoxycholate & $\begin{array}{c}86 \pm 16 \\
(6)\end{array}$ & $1.7 \pm 0.2$ & $15 \pm 1$ & $3 \pm 2$ & $0.7 \pm 0.6$ \\
\hline Taurodehydrocholate & $\begin{array}{c}110 \pm 25 \\
(6)\end{array}$ & $1.7 \pm 0.3$ & $15 \pm 2$ & $4 \pm 2$ & $0.4 \pm 0.3$ \\
\hline Triton WR-1339 & $\begin{array}{c}101 \pm 11 \\
(6)\end{array}$ & $1.4 \pm 0.3$ & $15 \pm 1$ & $5 \pm 3$ & $0.5 \pm 0.2$ \\
\hline
\end{tabular}

Bile salts $(100 \mathrm{mg} / 100 \mathrm{~g}$ body $\mathrm{wt})$ were administered orally except for taurodehydrocholate and the detergent Triton WR-1339 (22.5 $\mathrm{mg} / 100 \mathrm{~g}$ body $\mathrm{wt}$ ) that were given intraperitoneally $16 \mathrm{~h}$ before killing. $\left[{ }^{14} \mathrm{C}\right]$ Cholate binding and enzyme activities were measured in liver plasma membrane fractions (Methods). Results are expressed as the mean \pm SD. Numbers in parentheses indicate the individual determinations. $\cdot P<0.01$.

To examine the hypothesis that bile acid receptors are the in vitro equivalent of the carrier, we sought to examine a model of increased bile acid transport.
Adler et al. (17) first demonstrated and Watkins and Klassen (47) confirmed recently that expansion of the bile salt pool with taurocholate is associated with in-

TABLE VI

Effect of Oral Administration of Different Bile Salts on Biliary Secretory Function

\begin{tabular}{lccc}
\hline \multicolumn{1}{c}{ Treatment groups } & Initial bile flow & $\begin{array}{c}\text { Initial bile salt } \\
\text { excretion }\end{array}$ & Taurocholate Tm \\
\hline & $\mu l \cdot \mathrm{min} \cdot \mathrm{gliver}^{-1}$ & $\mathrm{nmol} \cdot \mathrm{min} \cdot \mathrm{g} \mathrm{liver^{-1 }}$ & $\mathrm{nmol} \cdot \mathrm{min} \cdot \mathrm{g}$ liver $^{-1}$ \\
Control (5) & $1.76 \pm 0.16$ & $46.3 \pm 3.3$ & $408.7 \pm 7.7$ \\
Taurocholate (4) & $2.43 \pm 0.12^{\circ}$ & $95.2 \pm 10.8^{\circ}$ & $653.0 \pm 109.11$ \\
Glycocholate (4) & $2.45 \pm 0.13^{\circ}$ & $114.0 \pm 28.5^{\circ}$ & $399.5 \pm 69.0$ \\
Chenodeoxycholate (4) & $1.73 \pm 0.16$ & $54.0 \pm 6.8$ & $313.1 \pm 29.4^{\circ}$ \\
\hline
\end{tabular}

Bile salts $(100 \mathrm{mg} / 100 \mathrm{~g}$ body $\mathrm{wt})$ were administered orally. $16 \mathrm{~h}$ later bile ducts were cannulated with PE 50 tubing and taurocholate Tm measured (Methods). Results are presented as the mean \pm SEM. Numbers in parentheses indicate separate experiments. $P<0.01, \downarrow P<0.05$. 
creased maximal transport capacity for taurocholate. As has been proposed for several organic anions, two general mechanisms were suggested for this increase in the maximum hepatic excretion of bile acids: $(a)$ recruitment of latent sites in hepatocytes from the pericentral zone III, and $(b)$ adaptation of the canalicular membrane transport process, including increased canalicular membrane surface area, lipid fluidity, and the numbers of bile salt carriers. The results of our studies strongly suggest that sodium cholate feeding increases bile salt transport in the liver through induction of putative bile acid carriers.

Biliary bile acid analysis demonstrates that cholate administration not only increased the ingested bile acid 11 -fold, but was also associated with a dramatic increase (33-fold) in deoxycholate, the major secondary bile salt of cholate. Sodium cholate feeding may also inhibit hepatic synthesis of the primary bile acid chenodeoxycholate and thus the formation of the following secondary bile acids: $\beta$-muricholate, hyodeoxycholate, lithocholate, and ursodeoxycholate. Thus, the bile acid pool is converted almost entirely to cholate and deoxycholate $(99 \%)$ by chronic sodium cholate treatment (Table II). Quantitatively similar changes have been reported in man (48).

As previously shown at $2 \mathrm{~d}$ with either oral administration or duodenal infusion of taurocholate $(17,47)$, expansion of the bile acid pool with oral sodium cholate also increased the maximum transport capacity for taurocholate 2.3-fold (Table III). However, this change in transport capacity was not selective since the Tm of BSP, an organic anion whose transport is separate from bile acids (11), was also increased 1.5fold. Since the original studies O'Maille et al. (36) on BSP $\mathrm{Tm}$, bile salts have been shown also to increase the biliary excretion of many other organic anions (4850). Whatever the specific mechanism for increased BSP $\mathrm{Tm}$, the striking difference in its time course for change $(<4 \mathrm{~h})$ compared with taurocholate transport $(2 \mathrm{~d})$ strongly suggests that increased bile salt transport is an adaptive process rather than a recruitment of latent sites. Furthermore, Watkins and Klassen (47) found that the biliary secretion of phenol-3,6-dibromphthalein and ouabain were not affected by oral taurocholate administration.

It is possible that increased bile acid $\mathrm{Tm}$ (as well as BSP Tm) simply represents an increase in the canalicular membrane surface area. Infusions of bile acids at $40 \mu \mathrm{mol} / \mathrm{h}$ have been shown to increase the canalicular diameter in zone III (52). However, these observations do not permit estimation of the canalicular membrane surface. Furthermore, these changes were noted as early as $1 \mathrm{~h}$ after infusion of taurocholate. Our data suggest the canalicular membrane surface does not increase since membrane protein recovery was unchanged. However, because this preparation contains a mixed population of membrane surfaces, we examined the effect of cholic acid on three enzymes believed to be primarily localized to the canalicular membrane (Table V): 5'-nucleotidase, leucine aminopeptidase, and $\mathrm{Mg}^{++}$-ATPase. Specific activities and relative specific activities were not changed by cholic acid treatment, suggesting that increased membrane surface area does not account for increased biliary transport.

It is well established that the optimal function of transport processes (53) as well as the activity of many membrane-bound enzymes are influenced by the membrane lipid composition (54). Since bile acid administration is known to inhibit cholesterol synthesis, and $\beta$-hydroxy- $\beta$-methyl glutarate $\operatorname{CoA}$ reductase activity (37), and to increase microsomal synthesis of specific phospholipids (55), it seemed possible that such changes may be reflected in the surface membrane lipid content. In an acute study using large amounts of taurocholate administered intraperitoneally in association with biliary drainage overnight, the phospholipid content of liver plasma membrane fractions was increased twofold (56). Such changes (i.e., decreased cholesterol to phospholipid molar ratios) are usually associated with increased membrane fluidity (41), and could theoretically be responsible for the increased bile acid Tm. However, no change in total phospholipid or cholesterol content was detected in liver surface membrane fractions from rats given cholic acid orally for $4 \mathrm{~d}$. These results suggest that increased transport functions are not directly related to an alteration in membrane lipid fluidity, although it is still possible that specific phospholipids may alter membrane transport.

Previous studies have demonstrated that the number of bile acid receptors may be rate limiting for hepatic transport (14). In this study, cholate administration was associated with an increased number of receptors whose binding kinetics were unchanged. It is unclear whether $\left[{ }^{14} \mathrm{C}\right]$ cholic acid binding is to the sinusoidal, canalicular, or both membrane domains. Several observations from the present study suggest $\left[{ }^{14} \mathrm{C}\right]$ cholic acid binding is quantitating canalicular sites: (a) Scatchard analysis of binding parameters in the basal state and after induction with cholate feeding demonstrated only a single class of binding sites (Fig. 2); and (b) either increases or decreases in the number of cholic acid binding sites was paralleled by similar changes in taurocholate Tm (Fig. 3 and Table VI).

Bile salts indirectly and directly affect many cellular systems, particularly membranes $(57,58)$. These changes have been shown to have a high degree of structural specificity. Such specificity was observed on the apparent induction of cholic acid binding sites, since only cholate and taurocholate significantly increased the maximum number of receptor sites (Table 
V). Since cholate is conjugated with taurine during its initial passage through the liver (20), it is not surprising that the increase with either conjugated or unconjugated cholate is similar, although statistically greater for taurocholate. Unexpectedly, this increase is seen only with the taurine but not the glycine conjugates of cholate (Table V and VI). Although chenodeoxycholate administration does not cause cholestasis, its oral administration significantly decreased the number of binding sites and taurocholate $\mathrm{Tm}$ proportionately. The specificity of these changes and the failure of a detergent (Triton WR-1339) to alter either parameter suggests that these receptors are measuring the putative canalicular carrier for bile salts.

In conclusion, cholate administration increases the maximum transport of bile salts probably through an adaptive increase in the maximum number of specific binding sites. This substrate-induced increase is the opposite of that described for most hormone receptors where so-called down regulation is usually seen (59), but is frequently seen with allosteric regulation of enzymes. Whether this increase in the liver surface membrane density of bile acid receptors is mediated through increased synthesis, decreased degradation, or a shifting from a possible intracellular pool to the surface membrane is unknown. Whatever the mechanism, it appears that the number of putative bile acid carriers adapt to the taurocholate pool size.

\section{ACKNOWLEDGMENTS}

The authors are grateful to Ms. Kathy Hunt for expert typing of the manuscript, to Ms. Patricia Coan for bile acid analysis, and to Dr. Fred Kern, Jr. and Dr. Susan VanScoyk for critical review of the manuscript.

Part of these studies were supported by U. S. Public Health Service grant AM-1581, Research Career Development Award (AM-00347) to Dr. Simon, and National Institutes of Health Fogarty International Fellowship (F05-2348) to Dr. Gonzalez.

\section{REFERENCES}

1. Matern, S., and W. Gerok. 1979. Pathophysiology of the enterohepatic circulation of bile acids. Rev. Physiol. Biochem. Pharmacol. 85: 126-204.

2. Schwarz, L. R., R. Burr, M. Schwenk, E. Pfaff, and H. Greim. 1975. Uptake of taurocholic acid into isolated rat liver cells. Eur. J. Biochem. 55: 617-623.

3. Reichen, J., and G. Paumgartner. 1975. Kinetics of taurocholate uptake by the perfused rat liver. Gastroenterology. 68: 132-136.

4. Wheeler, H. O., P. L. Mancusi-Ungaro, and P. T Whitlock. 1960. Bile salt transport in the dog. J. Clin. Invest. 39: 1039-1040.

5. O'Maille, E. R. L., T. G. Richards, and A. H, Short. 1965. Acute taurine depletion and maximum rates of hepatic conjugation and secretion of cholic acid in the dog. $J$. Physiol. (Lond.). 180: 67-79.

6. Schwarz, L. R., M. Schwenk, E. Pfaff, and H. Greim. 1976. Excretion of taurocholate from isolated hepatocytes. Eur. J. Biochem. 71: 369-373.
7. Arias, I. M., L. Johnson, and S. Wolfson. 1961. Biliary excretion of injected conjugated and unconjugated bilirubin by normal and Gunn rats. Am. J. Physiol. 200: 1091-1094.

8. Whelan, G., and B. Combes. 1975. Phenobarbital enhanced biliary excretion of administered unconjugated and conjugated sulfobromophthalein in the rat. Biochem. Pharmacol. 24: 1283-1286.

9. Paumgartner, G., K. Sauter, H. P. Schwarz, and R. Herz. 1973. Hepatic excretory maximum for free and conjugated cholate in the rat. In The Liver. Quantitative Aspects of Structure and Function. G. Paumgartner and R. Preisig, editors. S. Karger A. G., Basel. 337-343.

10. Reichen, J., and G. Paumgartner. 1976. Uptake of bile acids by the perfused rat liver. Am. J. Physiol. 231: 734742.

11. Alpert, S., M. Mosher, A. Shanske, and I. M. Arias. 1969. Multiplicity of hepatic excretory mechanisms for organic anions. J. Gen. Physiol. 53: 238-247.

12. Mueller, M. N., and A. Kappas. 1964. Impairment of hepatic excretion of sulfobromophthalein (BSP) by natural estrogens. Trans. Assoc. Am. Physicians. 77: 248257.

13. Accatino, L., and F. R. Simon. 1976. Identification and characterization of a bile acid receptor in isolated liver surface membranes. J. Clin. Invest. 57: 496-508.

14. Gonzalez, M. C., E. Sutherland, and F. R. Simon. 1979. Regulation of hepatic transport of bile salts: effect of protein synthesis inhibition on excretion of bile salts and their binding to liver surface membrane fractions. $J$. Clin. Invest. 63: 684-694.

15. Simon, R. R., M. Gonzalez, E. Sutherland, L. Accatino, and R. A. Davis. 1980. Reversal of ethinyl estradiol-induced bile secretory failure with Triton WR-1339. J. Clin. Invest. 65: 851-860.

16. Davis, R. A., F. Kern, Jr., R. Showalter, E. Sutherland, M. Sinensky, and F. R. Simon. 1978. Alterations of hepatic $\mathrm{Na}^{+} \mathrm{K}^{+}$-ATPase and bile flow by estrogens: effects on liver surface membrane lipid structure and function. Proc. Natl. Acad. Sci. U.S.A. 75: 4130-4134.

17. Adler, R. A., F. J. Wannagat, and R. Ockner. 1977. Bile secretion in selective biliary obstruction. Adaptation of taurocholate transport maximum to increased secretory load in the rat. Gastroenterology. 73: 129-136.

18. Mok, H. Y. I., P. M. Perry, and R. H. Dowling. 1974. The control of bile acid pool size: effect of jejunal resection and phenobarbitone on bile acid metabolism in the rat. Gut. 15: 247-253.

19. Talalay, P. 1960. Enzymatic analysis of steroid hormones. Methods Biochem. Anal. 8: 119-143.

20. Kern, F., Jr., H. Eriksson, T. Curstedt, and J. Sjovall. 1977. Effect of ethinyl estradiol on biliary excretion of bile acids, phosphatidylcholines, and cholesterol in the bile fistula of rat. J. Lipid Res. 18: 623-634.

21. Back, P., J. Sjovall, and K. Sjovall. 1974. Monohydroxy bile acids in plasma in intrahepatic cholestasis of pregnancy. Identification by computerized gas chromatography-mass spectrometry. Med. Biol. (Helsinki). 52: 3138.

22. Reyes, H., and F. Kern, Jr. 1979. Effect of pregnancy on bile flow and biliary lipids in the hamster. Gastroenterology. 76: 144-150.

23. Neville, D. M., Jr. 1968. Isolation of an organ-specific protein antigen from cell surface membrane of rat liver. Biochim. Biophys. Acta. 154: 540-552.

24. Pohl, S. L., L. Bernbaumer, and M. Rodbell. 1971. The glucagon-sensitive adenyl cyclase system in plasma membranes of rat liver. I Properties. J. Biol. Chem. 246: 1849-1856. 
25. Song, C. S., and O. Bodansky. 1967. Subcellular localization and properties of 5 '-nucleotidase in the rat liver. J. Biol. Chem. 242: 694-699.

26. DeDuve, C., B. C. Pressman, R. Gianetto, R. Wattiau, and F. Appelmans. 1955. Tissue fractionation studies. 6 intracellular distribution patterns of enzymes in rat liver tissue. Biochem. J. 60: 604-617.

27. Suebert, W. 1962. Butyryl-CoA and the CoA derivatives of the higher saturated fatty acids. In Methods in Enzymatic Analysis. H. U. von Bergmeyer, editor. Verlag Chemie Weinheim/Bergstr. 433-436.

28. Goldberg, J. A., and A. M. Ratenburg. 1958. The colorimetric determination of leucine aminopeptidase in urine and serum of normal subjects and patients with cancer and other diseases. Cancer. 11: 283-291.

29. Schoner, W., C. von Ilberg, R. Kramer, and W. Seubert. 1967. On the mechanism of $\mathrm{Na}^{+}$- and $\mathrm{K}^{+}$-stimulated hydrolysis of adenosine triphosphate. 1. Purification and properties of a $\mathrm{Na}^{+}$- and $\mathrm{K}^{+}$-activated ATPase from ox brain. Eur. J. Biochem. 1: 334-343.

30. Lowry, O. H., N. F. Rosebrough, A. L. Farr, and R. J. Randall. 1951. Protein measurement with the Folin phenol reagent. J. Biol. Chem. 193: 265-275.

31. Fiske, C. H., and Y. SubbaRow. 1925. The colorimetric determination of phosphorus. J. Biol. Chem. 66: 375400.

32. Bartlett, G. R. 1959. Phosphorus assay in column chromatography. J. Biol. Chem. 234: 466-468.

33. Folch, J., M. Lees, and G. H. Sloan-Stanley. 1957. A simple method for the isolation and purification of total lipids from animal tissues. J. Biol. Chem. 226: 497-509.

34. Davis, R. A., R. Showalter, and F. Kern, Jr. 1978. Reversal by Triton WR-1339 of ethinyl estradiol-induced hepatic cholesterol esterification. Biochem. J. 174: 4551 .

35. Binet, S., Y. Delage, and S. Erlinger. 1979. Influence of taurocholate, taurochenodeoxycholate, and taurodehydrocholate on sulfobromophthalein transport into bile. Am. J. Physiol. 236: E10-E14.

36. O'Maille, E. R. L., T. G. Richards, and A. H. Short. 1966. Factors determining the maximal rate of organic anion secretion by the liver and further evidence on the hepatic site of action of the hormone secretin. J. Physiol. (Lond.). 186: 424-438.

37. Carrella, M., and J. M. Dietschy. 1977. Comparison of the effects of cholic acid and chenic acid feeding on the rates of cholesterol synthesis in the liver of the rat. Am. J. Dig. Dis. 22: 318-326.

38. Hardison, W. G. M., and J. T. Apter. 1972. Micellar theory of biliary cholesterol excretion. Am. J. Physiol. 222: 61-67.

39. Swell, L., C. Entenman, G. F. Leong, and R. J. Holloway. 1968. Bile acids and lipid metabolism. IV. Influence of bile acids on biliary and liver organelle phospholipids and cholesterol. Am. J. Physiol. 215: 1390-1396.

40. Wheeler, H. O., and K. K. King. 1972. Biliary excretion of lecithin and cholesterol in the dog. J. Clin. Invest. 51: 1337-1350.

41. Cooper, R. A. 1977. Abnormalities of cell-membrane fluidity in the pathogenesis of disease. N. Engl. J. Med. 297: $371-377$.
42. Scatchard, G. 1949. The attractions of proteins for small molecules and ions. Ann. NY Acad. Sci. 5: 660-672.

43. Jones, A. L., G. T. Hradek, and R. H. Renston. 1980. Autoradiographic evidence for hepatic lobular concentration gradient of bile acid derivative. Am. J. Physiol. 238: G233-237.

44. Strange, R. C., I. A. Nimmo, and I. W. Percy-Robb. 1976. Equilibrium-dialysis studies of the interaction between cholic acid and $100,000 \mathrm{~g}$ supernatants prepared from rat liver. Biochem. J. 156: 427-433.

45. O'Maille, E. R. L. 1977. Bile salt secretion. Ir. J. Med. Sci. 146: 190-198.

46. Forker, E. L. 1977. Mechanisms of hepatic bile formation. Annu. Rev. Physiol. 39: 323-347.

47. Watkins, J. B., and C. D. Klaussen. 1981. Effect of repeated oral administration of taurocholate on hepatic excretory function in the rat. J. Pharmacol. Exp. Ther. 218: 182-187.

48. Thistle, J. L., and L. J. Schoenfield. 1971. Induced alterations in composition of bile of persons having cholelithiasis. Gastroenterology. 61: 488-496.

49. Goresky, C. A., H. H. Haddad, W. S. Kluger, B. E. Nadeau, and G. G. Bach. 1974. The enhancement of maximum bilirubin excretion with taurocholate-induced increments in bile flow. Can. J. Physiol. Pharmacol. 52: 389-403.

50. Vonk, R. J., H. v.d. Veen, G. Prop, and D. K. F. Meyer. 1974. The influence of taurocholate and dehydrocholate choleresis on plasma disappearance and biliary excretion of Indocyanine Green in the rat. Naunyn-Schmiedebergs Arch. Pharmakol. 282: 401-410.

51. Berk, R. N., L. E. Goldberger, and P. M. Loeb. 1974. The role of bile salts in the hepatic excretion of iopanoic acid. Invest. Radiol. 9: 7-15.

52. Layden, T. J., and J. L. Boyer. 1979. Recruitment of central lobular hepatocytes for bile acid-dependent bile secretion. In Biological Effects of Bile Acids, G. Paumgartner, A. Stiehl, and W. Gerok, editors. MTP Press Ltd., Lancaster, England.

53. Cronan, J. E., Jr., and E. P. Gelmann. 1975. Physical properties of membrane lipids: biological relevance and regulation. Bacteriol. Rev. 39: 232-256.

54. Sandermann, H., Jr. 1978. Regulation of membrane enzymes by lipids. Biochim. Biophys. Acta. 515: 209-237.

55. Balint, J. A., D. A. Beeler, E. C. Kyreakides, and D. H. Treble. 1971. The effect of bile salts upon lecithin synthesis. J. Lab. Clin. Med. 77: 122-131.

56. Nemchausky, B. A., T. J. Layden, and J. L. Boyer. 1977 Effects of chronic choleretic infusions of bile acids on the membrane of the bile canaliculus. A biochemical and morphological study. Lab. Invest. 36: 259-267.

57. Palmer, R. H. 1979. Bile acid heterogeneity and the gastrointestinal epithelium: from diarrhea to colon cancer. J. Lab. Clin. Med. 94: 655-660.

58. Lowe, P. J., and R. Coleman. 1981. Membrane fluidity and bile salt damage. Biochim. Biophys. Acta. 640: 5565 .

59. Soll, A. H. 1976. Hormonal regulation of hormone receptor concentration: a possible mechanism for altered sensitivity to hormones. In Biogenesis and Turnover of Membrane Macromolecules. J. D. Cook, editor. Raven Press, New York. 179-205. 